\title{
Mismatch repair genes status in sporadic Saudi colorectal cancer patients
}

\author{
Manar Ata ${ }^{1 *}$, Ashraf Dallol ${ }^{1}$, Jaudah Al-Maghrabi ${ }^{2}$, Abdulrahmn Al-Sibiany ${ }^{3}$, Mahmoud Al-Ahwal $^{4}$, \\ Mohammed Al-Qahtani', Abdelbaset Buhmeida' \\ From 2nd International Genomic Medical Conference (IGMC 2013) \\ Jeddah, Kingdom of Saudi Arabia. 24-27 November 2013
}

\section{Background}

Colorectal cancer (CRC) is becoming a major public health problem globally [1]. It ranks first in men and third in women of Saudi population according to Saudi Cancer Registry 2009 [2]. Many efforts have been directed toward assessment of best strategies for establishing molecular prognostic model $[3,4]$. In our study, we aimed to assess the prevalence of Mismatch Repair (MMR) genes defects in CRC and evaluate the concordance rate between Microsatellite Instability (MSI) and Immunohistochemistry (IHC).

\section{Materials and methods}

Two techniques were used: IHC using antibodies for MLH1 and MSH2 gene proteins and MSI tests using a panel of five Microsatellites' markers (BAT25, BAT26, D5S346, D2S123 and D17S250) that have been validated and recommended for tumor characterization as MSstable, MSI-H or MSI-L. DNA samples from tumors and normal tissues of 83 patients undergoing curative surgery of sporadic CRC were amplified using Polymerase chain reaction (PCR). PCR products were run on ABI prism 310 sequencer and GeneScan; version 310 software was used for analysis. Paraffinized tissue sections slides from the same patients tissues were used for IHC detection of MLH1 and MSH2 proteins.

\section{Results}

The prevalence of MSI-H, MSI-L and MS-stable were 44.6 $\%, 31.3 \%$ and $24.1 \%$ respectively. IHC identified 50 cases (60.2\%) with loss of expression of MLH1 and 40 cases (48.2\%) with loss of expression of MSH2. Concordance

\footnotetext{
* Correspondence: manar829@yahoo.com

${ }^{1}$ Center of Excellence in Genomic Medicine Research, King Abdulaziz

University, Jeddah, Saudi Arabia

Full list of author information is available at the end of the article
}

rate between MSI and IHC is 55.4\%. Furthermore, 28.9\% of no concordance is attributed to other MMR genes not included in our study.

\section{Conclusions}

MSI and IHC are complementary useful techniques for evaluation of MMR status. Further study with a large cohort is needed to evaluate correlation with clinicopathological characteristics and to be used as prognostics.

This work was financially supported by King Abdulaziz City for Science and Technology (KACST) under research no (ARP -30-262).

\section{Authors' details}

${ }^{1}$ Center of Excellence in Genomic Medicine Research, King Abdulaziz University, Jeddah, Saudi Arabia. ${ }^{2}$ Department of Pathology, King Abdulaziz University, Jeddah, Saudi Arabia. ${ }^{3}$ Department of Surgery, King Abdulaziz University, Jeddah, Saudi Arabia. ${ }^{4}$ Department of Oncology, King Abdulaziz University, Jeddah, Saudi Arabia.

Published: 2 April 2014

\section{References}

1. Poynter JN, Siegmund KD, Weisenberger DJ, Long TI: Colon Cancer Family Registry Investigators. Molecular characterization of MSI-H colorectal cancer by MLHI promoter methylation, immunohistochemistry, and mismatch repair germline mutation screening. Cancer Epidemiol Biomarkers Prev 2008, 17(11):3208-15.

2. Mosli MH, Al-Ahwal MS: Colorectal cancer in the Kingdom of Saudi Arabia: need for screening. Asian Pac J Cancer Prev 2012, 13(8):3809-13.

3. Boland CR, Thibodeau SN, Hamilton SR, Sidransky D, et al: A National Cancer Institute Workshop on Microsatellite Instability for cancer detection and familial predisposition: development of international criteria for the determination of microsatellite instability in colorectal cancer. Cancer Res 1998, 58(22):5248-57.

4. Yoon YS, Yu CS, Kim TW, Kim JH, Jang SJ, Cho DH, Roh SA, Kim JC: Mismatch repair status in sporadic colorectal cancer: immunohistochemistry and microsatellite instability analyses. J Gastroenterol Hepatol 2011, 26(12):1733-9.

doi:10.1186/1471-2164-15-S2-P57

Cite this article as: Ata et al:: Mismatch repair genes status in sporadic Saudi colorectal cancer patients. BMC Genomics 2014 15(Suppl 2):P57.
C Biomed Central

C 2014 Ata et al; licensee BioMed Central Ltd. This is an Open Access article distributed under the terms of the Creative Commons Attribution License (http://creativecommons.org/licenses/by/2.0), which permits unrestricted use, distribution, and reproduction in any medium, provided the original work is properly cited. 